\title{
Analisis Pengaruh Dana Pihak Ketiga dan Pembiayaan Terhadap Market Share Perbankan Syariah di Indonesia Melalui A set Sebagai Variabel Intervening
}

\author{
Vivin Wulandari*, Deky A nwar \\ Universitas Islam Negeri Raden Fatah, Palembang, Indonesia
}

\begin{abstract}
A bstract
Purpose- This study aims to analyze the direct and indirect effect of Third Party Funds (TPF) and Financing (PMBY) on the Market share (MS) of Indonesian Islamic Banking in 2013-2017, with asset variables (ASET) as intervening.

Methods- A quantitative research method was used. Data collection techniques in this study are documentation financial reporting. Panel data regression is used to test hypotheses using the EVIEWS program Findings- The results indicate that simultaneous, TPF, PMBY, and ASET have a positive and significant effect on the market share of Islamic banking. And partially, TPF does not affect MS, PMBY has a significant negative effect on $M S$, and assets have a significant positive effect on MS. ASET are not proven to be intervening on the tested model.

Research implications- This study can be a knowledge for investors to understand the market share of Islamic banking, as well as an evaluation material for management to increase market share through deposits, PMBY, and ASET.
\end{abstract}

Keywords Third-Party Funds (TPF), Financing (PMBY), ASET, Market share (MS)

Paper type Research paper

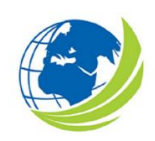

SERAMBI, Vol 1, No.2,

Agustus 2019,

pp. 33 - 44

elSSN 2685-9904

$\triangle$ Email korespondensi: komarudin.mepi3@gmail.com

\section{Pedoman Sitasi}

Vivin Wulandari \& Deky Anwar (2019). Analisis Pengaruh Dana Pihak ketiga dan Pembiayaan Terhadap Market Share Perbankan Syariah di Indonesia Melalui Aset Sebagai Variabel Intervening. SERAMBI, 1(2), $33-44$

D OI: https:/ / doi.org/ 10.36407/ serambi.v1i2.69 


\section{Pendahuluan}

Bank Syariah di Indonesia telah berjalan memasuki tahun ke-dua dekade, sejak berdirinya Bank Syariah di Indonesia untuk pertama kali pada tahun 1991, tepatnya pada tanggal 1 November 1991 (Muhammad, 2016). Bank Muamalat Indonesia (BMI) resmi beroperasi dengan modal awal sebesar Rp 106.126.382.000,-. Namun seiring dengan perkembangannya saat ini, market share Bank Syariah hanya mencapai 5,3\%, sedangkan target yang diberikan Otoritas Jasa Keuangan (OJK) yaitu market share di angka $20 \%$.

M arket share perbankan syariah di Indonesia masih berada jauh di bawah market share yang ditargetkan oleh OJK. Dan untuk mencapai market share yang ditargetkan sebesar $20 \%$, maka bank syariah akan menghadapi berbagai tantangan, di antaranya adalah tantangan produk yang kompetitif dengan porduk dari perbankan konvensional. Untuk mewujudkan produk yang kompetitif tersebut antara lain dengan pengembangan teknologi gadget untuk transaksi keuangan dan masuk ke pangsa pasar di Indonesia khususnya pada daerah terpencil, karena pasar di daerah terpencil sangatlah besar dan kebanyakan belum mengenal jenis-jenis keuangan. Namun, tingkat pertumbuhan bank syariah yang sudah memasuki tahun ke - 2 dekade, tepatnya sudah 26 tahun Bank Syariah berdiri di Indonesia, maka market share sebesar 4,77\% periode Desember 2016, ini dinilai sangat rendah mengingat perkembangan aset bank syariah yang terus meningkat.

Di sisi lain, perkembangan aset perbankan syariah Indonesia meningkat cukup signifikan. Hal ini ditunjukkan bahwa pertumbuhan nilai aset perbankan syariah tumbuh rata-rata mencapai $60-70 \%$ per tahun. Dan perkembangan aset perbankan syariah tersebut linier dengan perkembangan pembiayaan perbankan syariah yang juga ikut meningkat. Sejalan dengan peningkatan margin pembiayaan perbankan syariah dan aset perbankan syariah, profit perbankan syariah di Indonesia juga ikut meningkat, hal ini dapat dilihat berdasarkan data yang bersumber dari Statistik Perbankan Syariah yang menunjukkan peningkatan laba sebesar 14,79\%, dari laba sebesar 1,786 triliun pada Desember 2015 meningkat menjadi 2,096 triliun pada Desember 2016. Meskipun demikian, pencapaian tersebut berbanding terbalik dengan nilai market share yang dicapai oleh perbankan syariah masih termasuk rendah di angka 4,77\%.

Margin pembiayaan bank syariah di Indonesia meningkat dan ini sejalan dengan peningkatan aset bank syariah di Indonesia. Sehingga, penelitian ini akan menganalisa bagaimana pengaruh pembiayaan terhadap perbankan syariah di Indonesia. Dan, untuk menghadapi tantangan dalam meningkatkan market share perbankan syariah di Indonesia, dibutuhkan penelitian tentang variabelvariabel apa saja yang berpengaruh terhadap market share perbankan syariah di Indonesia.

Berdasarkan uraian di atas terlihat beberapa fenomena yang menarik untuk diteliti dan dianalisis, sehingga tujuan dari penelitian ini untuk menganalisis pengaruh langsung dan tidak langsung Dana Pihak Ketiga (TPF) dan Pembiayaan (PMBY) terhadap Pangsa Pasar (MS) Perbankan Syariah Indonesia pada 2013-2017, dengan variabel aset (ASET) sebagai intervensi. Hasil dari penelitian ini dapat memberikan pandangan dan masukan bagi stockholder dan stakeholder perbankan syariah di Indonesia.

\section{Kajian Teori}

Dana Pihak Ketiga (Third-Party Funds)

Dana Pihak Ketiga (Third-Party Funds/ TPF) merupakan dana yang dihimpun oleh pihak bank yang berasal dari masyarakat. Pertumbuhan setiap bank sangat dipengaruhi oleh perkembangan kemampuannya menghimpun dana dari masyarakat, baik berskala kecil maupun besar dengan masa pengendapan yang memadai (M uhammad, 2002). Dana merupakan masalah bank yang paling utama, tanpa dana bank tidak akan bisa berfungsi dengan baik. Dana Pihak Ketiga terdiri dari beberapa jenis, yaitu tabungan, deposito, giro. 
Vivin Wulandari \& Deky Anwar / A nalisis Pengaruh Dana Pihak Ketiga...

Pembiayaan

Bank-bank Islam pada umumnya menggunakan murabahah sebagai metode utama pembiayaan. Pembiayaan murabahah merupakan bentuk pembiayaan berprinsip jual beli yang pada dasarnya merupakan penjualan dengan keuntungan (margin) tertentu yang ditambahkan diatas biaya perolehan, di mana pelunasannya dapat dilakukan secara tunai maupun angsuran.

Pangsa Pasar (M arket Share)

Dalam perkembangan nya, aset perbankan syariah mengalami pertumbuhan $10 \%$ hingga $12 \%$ per tahun. Dan saat ini market share perbankan syariah sekitar 5,5\% dari total aset bank. Faktor utama peningkatan aset berasal dari kenaikan Dana Pihak Ketiga (DPK) yang juga tumbuh dan ekspansi pembiayaan, khususnya pembiayaan komersial. Sehingga apabila DPK dan pembiayaan meningkat akan berdampak terhadap peningkatan aset dan aset merupakan indikator market shareperbankan syariah.

A set

Dalam PSAK No. 16 Revisi Tahun 2011, disebutkan bahwa aset merupakan semua kekayaan yang dimiliki oleh seseorang atau perusahaan baik berwujud maupun tak berwujud yang berharga atau bernilai yang akan mendatangkan manfaat bagi seseorang atau perusahaan tersebut. Manfaat ekonomi masa depan yang terwujud dalam aset adalah potensi dari asset tersebut untuk memberikan sumbangan, baik langsung maupun tidak langsung, arus kas dan setara kas kepada perusahaan.

Ada beberapa definisi yang menjelaskan tentang aset. Dalam Pernyataan Standar Akuntansi Keuangan (PSAK) yang berlaku di Indonesia disebutkan bahwa aset adalah sumber daya yang dikuasai oleh perusahaan sebagai akibat dari peristiwa masa lalu dan diharapkan akan menghasilkan manfaat ekonomis di masa depan bagi perusahaan. Dalam International Financial Reporting Standards (2011) disebutkan bahwa "an asset is a resource controlled by the enterprise as a result of past events and from which future economic benefits are expected to flow to the enterprise."

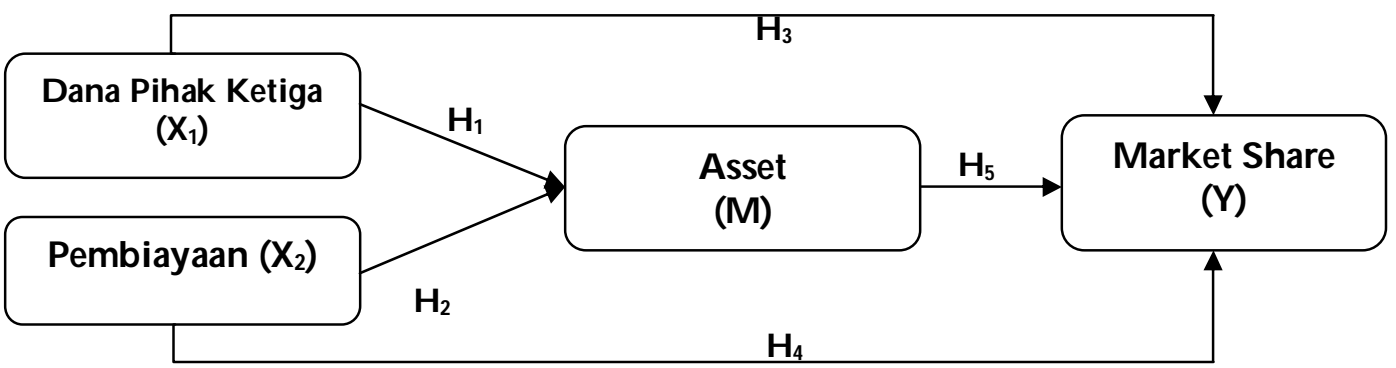

\section{G ambar 1. Kerangka Pemikiran}

\section{Metodologi Penelitian}

Desain Penelitian

Jenis data yang digunakan dalam penelitian ini adalah data sekunder. Data sekunder adalah data yang diperoleh dari bentuk yang sudah jadi, sudah dikumpulkan dan diolah oleh pihak lain. Data sekunder dalam penelitian ini terdiri dari data kualitatif dan data kuantitatif. Data kualitatif berupa informasi mengenai perkembangan market share perbankan syariah sedangkan data kuantitatif berupa data Dana Pihak Ketiga, Pembiayaan, dan Aset.

Semua data yang digunakan merupakan data bulanan semua bank komersial syariah sejak tahun 2013 sampai 2017. Kurun waktu tersebut dipilih dengan alasan keterbatasan sumber data yang dimiliki dan keterbatasan waktu tersedia (Basuki, 2018). Data yang dibutuhkan dalam penelitian ini 
diperoleh langsung dari OJK dan sebagian data juga diperoleh dengan mengutip dari website resminya yaitu http:/ / ojk.go.id.

Populasi dan Sampel

Populasi dalam penelitian ini adalah seluruh bank syariah yang mempublikasikan laporan keuangannya ke OJK. Teknik pengambilan sampel penelitian didasarkan pada purposive judment sampling dengan tujuan untuk mendapatkan sampel yang sesuai dengan kriteria yang telah ditentukan. purposive judment sampling adalah penentuan sampel dan pemilihan masing-masing item sampel nya diambil dengan dasar keputusan (judment) yang masuk akal menurut pengambil sampel. Adapun dalam penelitian ini menggunakan data dana panel, yang terdiri dari dari 5 data time series dan 11 data cross section, sehingga data berjumlah 55 .

Teknik A nalisis D ata

Teknik analisis data yang digunakan dalam penelitian ini adalah dengan metode analisis deskriptif kuantitatif yaitu data-data yang diperoleh kemudian dikumpulkan dan dianalisis berdasarkan metode yang telah ditetapkan dengan tujuan untuk mengetahui bagaimana pengaruh variabelvariabel independen, intervening, dan variabel dependen penelitian ini. Teknik analisis regresi data panel digunakan karena dapat menyimpulkan secara langsung variabel bebas yang digunakan baik secara parsial atau secara bersama-sama. Berdasarkan tujuan dari penelitian ini, maka metode analisis data yang digunakan dalam penelitian ini terdiri dari beberapa bagian, yaitu Regresi data panel merupakan metode regresi yang digunakan untuk memodelkan data panel. Berdasarkan judul penelitian, penelitian ini menggunakan model regresi data panel dan model analisis jalur, dimana kedua model tersebut akan digabungkan menjadi satu kesatuan.

\section{Hasil dan Pembahasan}

Dalam metode estimasi model regresi dengan menggunakan data panel dapat dilakukan dengan melalui tiga pendekatan, yaitu pendekatan Common Effect M odel, pendekatan Fixed Effect M odel, dan pendekatan Random Effect M odel. Pemilihan metode pengujian data panel dilakukan pada seluruh data sample yaitu 11 bank komersial syariah di Indonesia. Untuk memilih model yang paling tepat digunakan dalam mengel ola data panel, terdapat beberapa pengujian yang dapat dilakukan. Adapun hasil pengujian dari pendekatan di atas adalah sebagai berikut:

\section{Uji Chow Test}

Uji chow test yakni pengujian untuk menentukan model Common Effect atau Fixed Effect yang paling tepat digunakan dalam mengestimasi data panel. Bedasarkan hasil uji chow test di atas, dihasilkan nilai probabilitas Cross-section $\mathrm{F}$ sebesar 0.5446 lebih besar dari nilai alpha 0.05 maka Ho diterima dengan menolak $\mathrm{Ha}$. Maka, model yang digunakan dalam regresi data panel adalah model regresi common effect.

Uji Hausman Test

Dalam pengujian Hausman Test adalah pengujian statistik untuk memilih apakah model fixed effect atau random effect yang paling tepat digunakan. Bedasarkan hasil uji hausman test di atas, dihasilkan nilai probabilitas pada test Cross-section random effect sebesar 0.0297 lebih kecil dari nilai al pha 0.05 maka Ho diterima dengan menolak Ha. Maka, model yang digunakan dalam regresi data panel adalah model regresi random effect.

Uji Langrange M ultiplier (LM ) Test 
Vivin Wulandari \& Deky Anwar / A nalisis Pengaruh Dana Pihak Ketiga...

Berdasarkan hasil dari uji chow test dan uji hausman test menunjukkan dua kondisi yang berbeda, dimana hasil uji chow test menghasilkan model common effect yang terbaik untuk digunakan, sedangkan hasil uji hausman test menghasilkan model random effect yang terbaik untuk digunaka. Sehingga dibutuhkan Uji Langrange M ultiplier (LM) Test yakni pengujian untuk menentukan model common effect atau random effect yang paling tepat digunakan dalam mengestimasi data panel.

Bedasarkan hasil uji langrange multiplier (LM) test di atas, dihasilkan nilai $\mathrm{P}$ value dengan menggunakan metode Breusch Pagan, menunjukkan angka sebesar 0.0360 dimana nilainya kurang dari 0.05. Sehingga Langrange M ultiplier Test ini menunjukkan bahwa menerima Ha dengan menolak Ho yang berarti metode estimasi terbaik adalah random effect. Berdasarkan hasil dari Uji Chow, Uji Hausman, dan Uji Langrange Multiplier di atas, maka menghasilkan model random effect sebagai metode estimasi terbaik dalam regresi data panel pada penelitian ini.

\section{Estimasi Hasil Regresi Data Panel}

Uji Substruktur I

Substruktur I $Y_{1 \mathrm{it}}=\beta_{0}+\beta_{1} X_{1 \mathrm{it}}+\beta_{2} \mathrm{X}_{2 \mathrm{it}}+\mu_{\mathrm{it}}$

$Y_{1} \quad$ :ASET

$\mathrm{X}_{1} \quad$ :Dana Pihak Ketiga (DPK)

$\mathrm{X}_{2} \quad$ :Pembiayaan (PMBY)

$\mu_{\text {it }} \quad$ :Error

Berdasarkan uji spesifikasi model yang telah digunakan dengan analisis yang menggunakan uji Chow Test. Hasilnya menyatakan bahwa data yang baik digunakan adalah model random effect. Berikut ini hasil regresi substruktur I:

Tabel 1. M odel Regresi Random Effect Substruktur I

\begin{tabular}{|c|c|c|c|c|}
\hline \multicolumn{5}{|c|}{$\begin{array}{l}\text { Dependent Variable: ASET } \\
\text { Method: Panel EGLS (Cross-section random effects) } \\
\text { Date: O7/18/18 Time: } 19: 53 \\
\text { Sample: } 20132017 \\
\text { Periods included: } 5 \\
\text { Cross-sections included: } 11 \\
\text { Total panel (balanced) observations: } 55 \\
\text { Swamy and Arora estimator of component variances }\end{array}$} \\
\hline Variable & Coefficient & Std. Error & t-Statistic & Prob. \\
\hline $\begin{array}{c}\text { DPK } \\
\text { PMBY } \\
C\end{array}$ & $\begin{array}{l}0.801384 \\
0.427168 \\
459157.6\end{array}$ & $\begin{array}{l}0.078059 \\
0.096252 \\
214608.0\end{array}$ & $\begin{array}{l}10.26636 \\
4.438020 \\
2.139518\end{array}$ & $\begin{array}{l}0.0000 \\
0.0000 \\
0.0371\end{array}$ \\
\hline $\begin{array}{l}\text { R-squared } \\
\text { Adjusted R-squared } \\
\text { S.E. of regression } \\
\text { F-statistic }\end{array}$ & $\begin{array}{l}0.997043 \\
0.996929 \\
982539.4 \\
8765.982\end{array}$ & $\begin{array}{l}\text { Mean depen } \\
\text { S.D. depend } \\
\text { Sum square } \\
\text { Durbin-wats }\end{array}$ & $\begin{array}{l}\text { nt var } \\
\text { t var } \\
\text { esid } \\
\text { stat }\end{array}$ & $\begin{array}{l}14242668 \\
17730113 \\
5.02 E+13 \\
0.561737\end{array}$ \\
\hline
\end{tabular}

Sumber: Data diolah

Koefisien D eterminasi $\left(R^{2}\right)$

R-squared adalah sebuah ukuran untuk mengukur seberapa besar variabel eksogen mampu menjelaskan variabel endogennya. Pada uji substruktur I ini variabel eksogennya adalah DPK dan PMBY sedangkan variabel endogennya adalah ASET. Berdasarkan hasil estimasi untuk model regresi panel dilihat dari besarnya angka $\mathrm{R}^{2}$ adalah 0,997. Hal tersebut menunjukkan bahwa pengaruh variabel DPK dan PMBY terhadap ASET secara bersama-sama berpengaruh sebesar 99,7 persen sedangkan sisanya 0,3 persen lainnya dipengaruhi oleh faktor lain di luar penelitian.

Uji Simultan (F)

Uji F-statistik adalah uji kelayakan model yang digunakan untuk melihat pengaruh variabel DPK dan PMBY secara bersama-sama mampu mempengaruhi variabel ASET. Pengujian ini dengan melihat nilai prob (F-statistik). Berdasarkan hasil penelitian ini menunjukkan bahwasanya nilai prob (F-Statistik) sebesar 0,000 < 0.005 maka dapat disimpulkan bahwa model regresi ini sudah layak dan benar serta adanya hubungan linier antara variabel DPK dan PMBY dan menunjukkan bahwasanya DPK dan PMBY secara bersama-sama mampu mempengaruhi ASET. 
Uji Parsial (t)

Uji t-statistik adalah uji yang ditujukan untuk mengetahui seberapa besar pengaruh variabel DPK dan PMBY secara individu atau parsial mampu mempengaruhi variabel ASET. Pengujian ini dengan melihat nilai t-statistik dan nilai signifikansinya. A pabila nilai signifikansi t-statistik $<0.05$ maka variabel eksogen tersebut mampu mempengaruhi variabel endogen. Berdasarkan hasil perhitungan, diperoleh angka t-statistik variabel DPK sebesar 10.266 dan nilai t-tabel sebesar 1.674. Maka t-statistik $>t$ tabel menjelaskan bahwa $\mathrm{H}_{0}$ berhasil ditolak dan ada hubungan linier antara DPK dan ASET dan pengaruhnya bertanda positif. Hal ini berarti apabila DPK mengalami peningkatan maka ASET juga akan mengalami peningkatan.

Berdasarkan hasil perhitungan, diperoleh angka t-statistik variabel PMBY sebesar 4.438. Maka $\mathrm{t}$-statistik > t tabel menjelaskan bahwa $\mathrm{H}_{0}$ berhasil ditolak dan ada hubungan linier antara PMBY dan ASET dan pengaruhnya bertanda positif. $\mathrm{Hal}$ ini berarti apabila PMBY mengalami peningkatan maka ASET juga akan mengalami peningkatan.

Uji Substruktur II

$\begin{array}{ll}\text { Substruktur II: } \mathrm{Y}_{2 \mathrm{it}}=\beta_{0}+\beta_{3} \mathrm{X}_{1 \mathrm{it}}+\beta_{4} \mathrm{Y}_{1} \mathrm{Y}_{2 \mathrm{it}}+\beta_{5} \mathrm{X}_{2 \mathrm{it}}+\mu_{\mathrm{it}} \\ \mathrm{Y}_{1} & =\text { A SET } \\ \mathrm{Y}_{2} & =\text { M arket Share (MS) } \\ \mathrm{X}_{1} & =\text { Dana Pihak Ketiga (DPK) } \\ \mathrm{X}_{2} & =\text { Pembiayaan (PMBY) }\end{array}$

Berdasarkan uji spesifikasi model yang telah digunakan dengan analisis yang menggunakan uji Chow Test. Hasilnya menyatakan bahwa data yang baik digunakan adalah model ran dom effect. Berikut hasil regresi substruktur II:

Tabel 2. M odel Regresi Random Effect Substruktur II

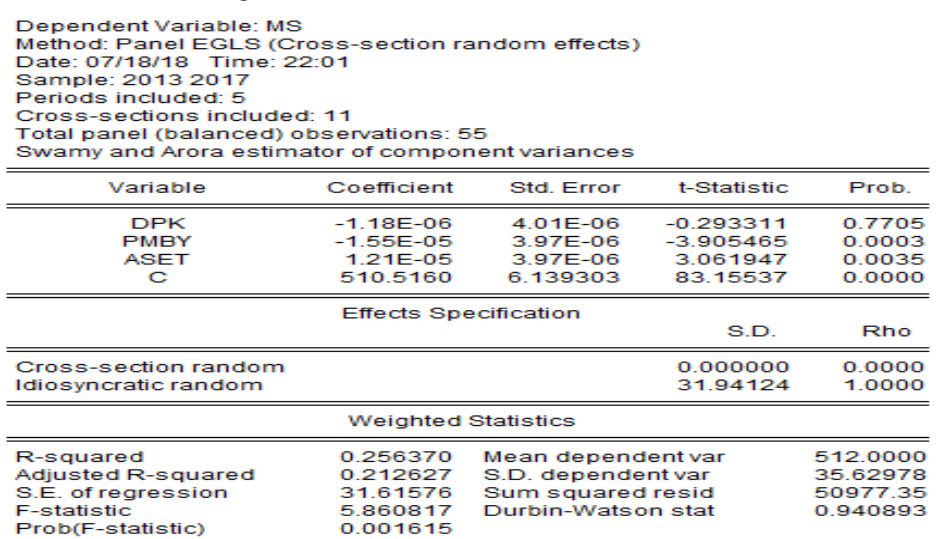

Sumber: Data diolah

Koefisien D eterminasi $\left(R^{2}\right)$

Berdasarkan hasil estimasi untuk model regresi panel dilihat dari besarnya angka $\mathrm{R}^{2}$ adalah 0,256 . Hal tersebut menunjukkan bahwa pengaruh variabel DPK, PMBY, dan ASET secara bersama-sama berpengaruh sebesar 25,6 persen sedangkan sisanya 74,4 persen lai nnya dipengaruhi oleh faktor lain di luar penelitian.

Uji Simultan (F)

Berdasarkan hasil penelitian ini menunjukkan bahwasanya nilai prob (F-Statistik) sebesar 0.001615 < 0.005 maka dapat disimpulkan bahwa model regresi ini sudah layak dan benar serta adanya 
hubungan linier antara variabel DPK, PMBY, dan ASET dan menunjukkan bahwasanya DPK, PMBY, dan ASET secara bersama-sama mampu mempengaruhi MS.

Uji Parsial (t)

Berdasarkan hasil perhitungan, diperoleh angka t-statistik variabel DPK sebesar -0.293 Maka tstatistik < t tabel menjelaskan bahwa Hoditerima dan tidak ada hubungan linier antara DPK dan MS dan pengaruhnya bertanda negatif. Dan DPK tidak signifikan karena dilihat dari nilai signifikan antara variabel DPK terhadap MS adalah $0,77<0.05$. Hal ini berarti apabila DPK mengalami peningkatan/ penurunan maka tidak akan berpengaruh terhadap MS.

Berdasarkan hasil perhitungan, diperoleh angka t-statistik variabel PMBY sebesar -3.905, maka t-statistik > t tabel menjelaskan bahwa $\mathrm{H}_{0}$ berhasil ditolak dan ada hubungan linier antara PMBY dan MS dan pengaruhnya bertanda negatif. Hal ini berarti apabila PMBY mengalami peningkatan maka MS akan mengalami penurunan begitupun sebaliknya. Dan, nilai t-statistik variabel ASET sebesar 3.061 dengan angka t-tabel sebesar 1.674, maka t-statistik $>\mathrm{t}$ tabel menjelaskan bahwa $\mathrm{H}_{0}$ berhasil ditolak dan ada hubungan linier antara ASET dan MS dan pengaruhnya bertanda positif. Hal ini berarti apabila ASET mengalami peningkatan maka MS juga akan mengalami peningkatan.

Uji Sobel Test

Sobel Test merupakan uji signifikansi koefisien mediasi dengan kriteria apabila t koefisien mediasi >tsobel maka variabel intervening mampu memediasi variabel eksogen terhadap variabel endogennya.

\section{Pengaruh DPK terhadap MS melalui ASET}

Berdasarkan hasil perhitungan, diperoleh angka t-statistik variabel DPK sebesar -0.293 dengan taraf signifikan 0.05 dan degree of freedom diperoleh df $=55-2-1=52$. Dari ketentuan tersebut diperoleh

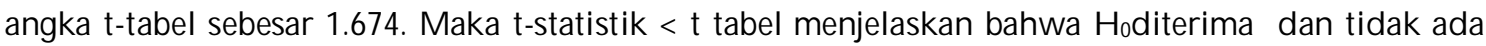
hubungan linier antara DPK dan MS dan pengaruhnya bertanda negatif. Dan DPK tidak signifikan, karena dilihat dari nilai signifikan variabel DPK terhadap yaitu $0,77>0.05$. Hal ini berarti apabila DPK mengalami peningkatan/ penurunan maka tidak akan berpengaruh terhadap MS. Maka hipotesis pertama dalam penelitian ini diterima.

Dana merupakan kebutuhan vital bagi sebuah bank sebagai lembaga keuangan guna mejalankan segala kegiatan operasionalnya, tanpa dana maka bank tidak bisa berbuat apa-apa. Dan DPK merupakan komposisi dana terbesar yang terdapat di bank syariah. DPK merupakan penggerak utama bank syariah dalam menjalankan fungsinya sebagai lembaga intermediasi.

Secara ekonomi perbankan syariah memiliki jumlah DPK yang cukup tinggi, hal ini sejalan dengan MS yang juga mengalami peningkatan selama periode tahun penelitian. Peningkatan yang sejalan antara DPK dan MS ternyata tidak membuktikan bahwa terdapat hubungan antara DPK dan MS. Hal ini bisa dilihat dari hasil penlitian ini yang menunjukkan tidak adanya pengaruh antara DPK dan MS.

Dana Pihak Ketiga merupakan sumber dana yang digunakan bank syariah untuk menyalurkan pembiayaan kepada masyarakat. Semakin banyak Dana Pihak Ketiga yang disalurkan, maka akan semakin banyak juga pembiayaan yang harus disalurkan oleh bank syariah. Bank syariah harus bisa mengelola Dana Pihak Ketiga secara efektif dan efisien, hal ini dikarenakan bank syariah berkewajiban untuk membagikan keuntungan kepada nasabah yang mempercayakan dana nya kepada bank syariah. Bank syariah dalam kaitannya dengan Dana Pihak Ketiga (DPK) belum bisa menghimpun dana murah yang lebih besar dibandingkan dana mahal. Dana murah yang dimaksud adalah tabungan dan giro, sedangkan dana mahal adalah deposito.

DPK perbankan syariah masih didominasi oleh dana mahal, hal ini dikarenakan dana murah masih dominan dikuasai oleh bank konvensional. Banyaknya DPK yang diperoleh oleh bank syariah juga mengakibatkan banyaknya pembiayaan yang harus disalurkan, akan tetapi keuntungan dari 
hasil pembiayaan yang disalurkan tidak terlalu signifikan. Karena bank berkewajiban menanggung biaya operasional yang tidak dibebankan kepada nasabah dan berkewajiban juga untuk membagikan keuntungan kepada nasabah sebagai imbal hasil dari dana mahal deposito.

Sehingga, banyaknya DPK bank syariah akan sejalan dengan banyaknya pembiayaan yang disalurkan, menyebabkan meningkatnya biaya yang harus di keluarkan dan bertambah kewajiban pembagian keuntungan kepada nasabah. Dengan kata lain DPK yang diperoleh oleh bank syariah tidak efektif terhadap pembiayaan, sehingga DPK tidak berpengaruh terhadap M arket Share (MS). Sehingga temuan ini membuktikkan tidak adanya pengaruh antara DPK dan MS mengindikasikan bahwa ada variabel lain yang mempengaruhi MS perbankan syariah bukan DPK. Hasil penelitian ini tidak sesuai dengan hasil penelitian terdahulu, yaitu hasil peneltian Purboastuti (2015) menyimpulkan bahwa DPK berpengaruh positif terhadap pangsa pasar perbankan syariah di Indonesia.

\section{Pengaruh DPK terhadap ASET}

Tidak adanya hubungan dan pengaruh antara DPK dan MS, maka variabel DPK perlu dimediasi dengan variabel lain agar mampu mempengaruhi MS. Ditinjau dari hubungan antara DPK terhadap MS melalui ASET berdasarkan hasil perhitungan, diperoleh angka statistik sebesar 10.266 dengan taraf signifikan 0.05 dan degree of freedom diperoleh $\mathrm{df}=55-2-1=52$. Dari ketentuan tersebut diperoleh angka t-tabel sebesar 1.674. Maka t-statistik > t tabel menjelaskan bahwa $\mathrm{H}_{0}$ berhasil ditolak dan ada hubungan linier antara DPK dan ASET dan pengaruhnya bertanda positif. Hal ini berarti apabila DPK mengalami peningkatan maka ASET juga akan mengalami peningkatan. Selain itu, dilihat dari nilai signifikan variabel DPK terhadap ASET yaitu $0,000<0,05$ maka hubungan antara variabel DPK dan ASET secara parsial memiliki hubungan yang signifikan. Hasil penelitian ini yang menyatakan bahwa DPK berpengaruh positif terhadap ASET sejalan dengan hasil penelitian Hidayah (2008) yang menyimpulkan bahwa DPK berpengaruh positif terhadap ASET perbankan Syariah.

Berdasarkan hasil penelitian yang menyatakan bahwa DPK berpengaruh terhadap ASET, maka ini berarti DPK yang dihimpun telah dioptimalkan pengelolaan nya oleh bank syariah. Secara teori, aset adalah sumber daya yang dikuasai entitas syariah masa kini yang timbul dari peristiwa masa lalu dan dari mana manfaat eknomi masa depan diharapkan akan diperoleh entitas syariah. Berdasarkan teori tersebut, maka yang termasuk dalam komponen aset, diantaranya adalah kas, piutang (dalam bentuk pembiayaan), persediaan, dan aset tetap.

Dalam hal ini, maka pengaruh DPK terhadap aset dalam penelitian ini berhubungan dengan salah satu komponen aset, yaitu pembiayaan. Karena DPK merupakan sumber dana terbesar bagi bank dalam menyalurkan pembiayaannya. DPK yang berhasil dihimpun oleh bank syariah apabila telah berhasil dikelola secara produktif, maka akan berpengaruh positif terhadap pembiayaan yang berarti pembiayaan akan meningkat sejalan dengan peningkatan DPK bank syariah. Dan pembiayaan merupakan salah satu aset bank syariah. Sehingga dengan meningkatnya DPK maka meningkatkan pula tingkat pembiayaan yang disalurkan oleh bank syariah, yang mengindikasikan bahwa bank telah menjalankan fungsinya sebagai lembaga intermediasi dengan optimal.

Peningkatan DPK yang berpengaruh positif terhadap aset, tidak hanya berpengaruh pada pembiayaan, tetapi bisa juga berpengaruh terhadap komponen aset yang lain, seperti kas, aset tetap, persediaan, dll. Akan tetapi apabila DPK disalurkan dalam bentuk pembiayaan, maka DPK ini akan menjadi efektif dan efisien dengan asumsi tingkat pengembalian dalam kondisi normal atau nilai NPF yang rendah. Sehingga pengaruh positif antara DPK dan ASET akan berdampak positif bagi bank, karen akan mendapatkan keuntungan dari pengelolaan DPK yang berhasil dihimpun oleh bank syariah.

Pengaruh A SET terhadap M S 
Pengaruh ASET terhadap MS dilihat dari nilai signifikan variabel ASET dan MS yaitu $0,0035<0,05$ maka hubungan antara variabel ASET dan MS secara parsial memiliki hubungan yang signifikan. Hal ini sesuai dengan hipotesis penelitian yang menyatakan bahwa ASET berpengaruh positif signifikan terhadap MS. Artinya setiap kenaikan yang dilakukan oleh ASET maka akan berimplikasi terhadap peningkatan MS perbankan syariah.

Berdasarkan hasil penelitian yang menunjukkan tidak ada pengaruh antara DPK dan ASET, dan menunjukkan pengaruh positif antara DPK dan ASET, maka selanjutnya diteliti bagaimana pengaruh ASET terhadap MS guna melihat pengaruh tidak langsung antara DPK dan MS. Yaitu, dengan melihat pengaruh DPK terhadap MS melalui ASET.

Variabel eksogen DPK menunjukkan bahwa tidak adanya hubungan linier antara DPK dan MS, hal ini dapat dilihat dari nilai signifikansi $0,7705>0,05$. Sehingga tidak ada pengaruh langsung antara DPK dan MS. Sedangkan pengaruh tidak langsung DPK terhadap MS sebesar $(0,80 \times 1,21)=2,01$. Pengaruh DPK terhadap ASET memiliki pengaruh positif dan signifikan. Hasil penelitian ini, sejalan dengan hasil peneltian terdahulu Nurkhotimah (2017) yang menyimpulkan bahwa aset berpengaruh positif signifikan terhadap market share bank syariah. Maka hal ini dapat disimpulkan bahwasanya ASET mampu memediasi DPK secara parsial. Namun besarnya koefisien jalur antara DPK terhadap MS tidak signifikan yang artinya ASET tidak konsisten dalam memediasi DPK dan MS.

Secara teori, indikator MS perbankan syariah adalah ASET, sehingga DPK yang tidak berpengaruh secara langsung terhadap ASET harus dimediasi untuk bisa mempengaruhi MS secara tidak langsung. Dalam hal ini, maka ASET dijadikan sebagai variabel intervening antara DPK dan MS. Dan hasil penelitian menunjukkan bahwa variabel ASET mampu memediasi DPK dan MS. Karena DPK dan ASET berpengaruh positif, dan ASET terhadap MS juga berpengaruh positif, bahkan memiliki pengaruh yang cukup besar yaitu 1,21 atau sama dengan $121 \%$.

Berdasarkan hasil di atas, maka untuk meningkatkan MS perbankan syariah harus meningkatkan ASET, dan ASET perbankan syariah bisa ditingkatkan dengan meningkatkan DPK. Akan tetapi, DPK yang dihimpun oleh bank syariah harus lebih difokuskan dan diupayakan untuk bisa menghimpun DPK dalam bentuk dana murah. Agar mampu memberikan kontribusi positif terhadap bank syariah.

\section{Pengaruh PMBY terhadap MS melal ui ASET}

Pengaruh PM BY terhadap M S

Dilihat dari pengaruh PMBY terhadap MS berdasarkan hasil perhitungan, diperoleh angka t-statistik variabel PMBY sebesar -3.905 dengan taraf signifikan 0.05 dan degree of freedom diperoleh df $=55-2-1=$ 52. Dari ketentuan tersebut diperoleh angka t-tabel sebesar 1.674. Maka t-statistik $>\mathrm{t}$ tabel menjelaskan bahwa $\mathrm{H}_{0}$ berhasil ditolak dan ada hubungan linier antara PMBY dan MS dan pengaruhnya bertanda negatif. Penelitian ini tidak sesuai dengan penelitian terdahulu, Asmoro (2018) menyimpulkan bahwa pembiayaan memiliki pengaruh yang positif dan signifikan terhadap $\mathrm{M}$ arket Share Perbankan Syariah. Hal ini berarti apabila PMBY mengalami peningkatan maka MS akan mengalami penurunan begitupun sebaliknya. Selain itu dilihat dari nilai signifikan, 0,0003<005 yang berarti bahwa terdapat hubungan signifikan antara PMBY dan ASET.

Berdasarkan hal tersebut, mengindikasikan bahwa apabila bank syariah meningkatkan jumlah pembiayaan, maka akan berpengaruh terhadap penurunan market share bank syariah. Hubungan negatif dan signifikan tersebut dapat ditarik argumen, kurangnya efektifitas bank dalam menempatkan dana-dana bank yang menghasilakan profit yang lebih besar. Penyaluran pembiayaan di bank syariah masih didominasi kepada penyaluran pembiayaan kredit, seperti murabahah dan jenis pembiayaan konsumtif. Sehingga keuntungan yang diperoleh bank syariah juga terbatas, adanya risiko terhadap pembiayaan macet, dan biaya operasional yang meningkat seiring bertambahnya pembiayaan, mengakibatkan hasil keuntungan dari pembiayaan dialokasikan kepada biaya 
operasional bank syariah. Sehingga mengakibatkan semakin banyak pembiayaan maka aset bank syariah semakin berkurang. Hal ini dikarenakan kebutuhan dana bank syariah semakin besar, sedangkan hasil keuntungan dari pembiayaan tidak terlalu besar.

Pengaruh PM BY terhadap ASET

Berdasarkan hasil perhitungan, diperoleh angka t-statistik variabel PMBY sebesar 4.438 dengan taraf signifikan 0.05 dan degree of freedom diperoleh df $=55-2-1=52$. Dari ketentuan tersebut diperoleh angka t-tabel sebesar 1.674. Maka t-statistik > t tabel menjelaskan bahwa $\mathrm{H}_{0}$ berhasil ditolak dan ada hubungan linier antara PMBY dan ASET dan pengaruhnya bertanda positif. Penelitian ini sesuai dengan penelitian terdahulu oleh Santoso (2018) menyimpulkan bahwa Pembiayaan berpengaruh positif signifikan terhadap Total Aset. Hal ini berarti apabila PMBY mengalami peningkatan maka ASET juga akan mengalami peningkatan. Selain itu nilai signifikan menunjukkan angka 0,0000, 0,05 yang berarti PMBY berpengaruh signifikan terhadap ASET.

Berdasarkan hal tesebut mengindikasikan bahwa apabila bank syariah meningkatkan pembiayaan, maka hal ini akan berpengaruh terhadap peningkatan jumlah aset bank syariah. Pembiayaan merupakan sumber utama bagi perbankan syariah dalam menghasilkan keuntungan. Sehingga semakin banyak pembiayaan yang disalurkan dengan asumsi minimnya pembiayaan macet, maka akan meningkatkan keuntungan bank, dan dapat berkontibusi terhadap peningkatan aset bank syariah. Dengan melihat adanya pengaruh antara PMBY dan ASET, maka pembiayaan yang disalurkan oleh bank syariah harus dilakukan secara efektif dan efisien dengan menjaga nilai NPF perbankan syariah. Hal ini guna menjaga kestabilan kesehatan perbankan syariah.

Pengaruh A SET terhadap M S

Pengaruh ASET terhadap MS dilihat dari nilai signifikan variabel ASET dan MS yaitu $0,0035<0,05$ maka hubungan antara variabel ASET dan MS secara parsial memiliki hubungan yang signifikan. Hal ini sesuai dengan hipotesis penelitian yang menyatakan bahwa ASET berpengaruh positif signifikan terhadap MS. Artinya setiap kenaikan yang dilakukan oleh ASET maka akan berimplikasi terhadap peningkatan MS perbankan syariah, serta pengaruh aset terhadap market share bank syariah sangat tinggi, yaitu berdasarkan nilai beta hubungannya sebesar 1,21 atau 121 persen. Hal ini dikarenakan aset merupakan indikator utama untuk melihat tingkat market share bank syariah.

Variabel eksogen PMBY menunjukkan bahwa adanya hubungan linier antara PMBY dan MS, hal ini dapat dilihat dari nilai signifikansi $0,0003<0,05$. Sehingga ada pengaruh langsung antara PMBY dan MS. Sedangkan pengaruh tidak langsung PMBY terhadap MS sebesar $(0,42 \times 1,21)=0,508$. Pengaruh PMBY terhadap ASET memiliki pengaruh positif dan signifikan. Hasil penelitian ini, sejalan dengan hasil peneltian terdahulu yaitu Nurkhotimah (2017) menyimpulkan bahwa aset berpengaruh positif signifikan terhadap market share bank syariah. Maka hal ini dapat disimpulkan bahwasanya ASET mampu memediasi PMBY secara parsial. Namun besarnya koefisien jalur antara PMBY terhadap MS tidak signifikan yang ar tinya ASET tidak konsisten dalam memediasi PMBY dan MS.

\section{Kesimpulan}

Secara simultan, hasil penelitian ini menunjukkan bahwa dari semua variabel independen, yaitu DPK, PMBY, dan ASET secara bersama-sama berpengaruh positif dan signifikan terhadap M arket Share (MS) perbankan syariah. Dan secara parsial bahwa DPK dan Pembiayaan (PMBY) berpengaruh positif dan signifikan terhadap ASET perbankan syariah. Hal ini berarti, apabila DPK dan PMBY mengalami peningkatan, maka ASET juga akan mengalami peningkatan. Variabel ASET berpengaruh positif signifikan terhadap M arket Share (MS) perbankan syariah, tetapi DPK tidak berpengaruh terhadap MS 
dan PMBY berpengaruh negatif terhadap MS, sehingga apabila PMBY mengalami peningkatan maka MS akan mengalami penurunan.

DPK terhadap MS melalui variabel ASET sebagai variabel intervening memiliki nilai koefisien jalur yang tidak signifikan sehingga ASET belum mampu memediasi antara DPK dan MS. Kemudian pengaruh variabel PMBY terhadap MS melalui variabel ASET sebagai variabel intervening memiliki nilai koefisien jalur yang tidak signifikan sehingga ASET tidak mampu memediasi antara PMBY dan MS. Maka dapat disimpulkan ASET hanya bertindak sebagai variabel independen.

Implikasi

Penelitian ini dapat menjadi pengetahuan bagi investor untuk memahami pangsa pasar perbankan syariah, serta bahan evaluasi bagi manajemen untuk meningkatkan pangsa pasar melalui deposito, PMBY, dan ASET.

Saran U ntuk Penelitian M endatang

Penelitian selanjutnya, dapat menambahkan cakupan penelitian, variasi dari variabel penelitian yang berhubungan dengan market share, sehingga hasil penelitian dapat bervariasi dan dapat digeneralisasi. Periode pengumpulan data, juga diperluas kembali untuk mendapatkan jumlah sampel yang lebih banyak dengan penambahan lembaga perbankan dan non perbankan di sektor syariah.

\section{Referensi}

Abdul Majid. (2008). http:/ / majidbsz.wordpress.com/ 2008/ 06/ 30/ pengertiankonsep-definisipemasaran/ .

Anshori, A. G. (2008). Sejarah Perkembangan Hukum Perbankan Syariah di Indonesia dan Implikasinya bagi Praktik Perbankan Nasional. Jurnal Fakultas H ukum U II , 2(2), 159-172.

Antonio, M. S. I. (2001). Bank Syariah: dari teori ke praktik. Gema Insani.

Arif, A., \& Rianto, M. N . (2010). Dasar-Dasar Pemasaran Bank Syariah. Bandung: A lfabeta.

Arikunto, S. (2010). Prosedur penelitian. Jakarta: Rineka Cipta.

Ascarya. (2007). A kad dan Produk Bank Syariah. Jakarta: Raja Grafindo Persada.

Asmoro, W. P.Analisis Faktor-Faktor Yang Mempengaruhi Market Share Bank Syariah Di Indonesia (Bachelor's thesis, Jakarta: Fakultas Ekonomi dan Bisnis UIN Syarif Hidayatullah Jakarta).

Bank Indonesia. (2009). Booklet Perbankan Indonesia. Jakarta, Indonesia.

Basuki, A.T. (2017). A nal isis R egresi D alam Penelitian Ekonomi dan Bisnis. Jakarta: Raja Grafindo Persada.

Greuning, et al. (2011). International Financial Reporting Standard A Practical Guide, 6 Edition. Washington D.C : The World Bank.

Hakim, C. M. (2011). Belajar mudah ekonomi Islam: catatan kritis terhadap dinamika perkembangan perbankan syariah di Indonesia. Shuhuf Media Insani.

Hasan, H. (2011). Analisis Industri Perbankan Syariah Di Indonesia. Jurnal Dinamika Ekonomi Pembangunan, 1(1), 1-183.

Hidayah, E. H. N. (2008). Faktor yang mempengaruhi pertumbuhan aset Perbankan Syariah (Doctoral dissertation, Universitas Indonesia. Program Pascasarjana).

Huda, N., dkk. (2017). Pemasaran Syariah, Teori dan A plikasi. Depok: Kencana.

Ikatan A kuntansi Indonesia. (2011). Standar A kuntansi Keuangan, Revisi. Jakarta: IAI.

Ismail, M. B. A. (2018). M anaj eman Perbankan: D ari T eori M enuju A plikasi . Kencana.

Karim, A. (2008). Bank Islam: A nal isis Fiqih dan Keuangan. Jakarta: Raja Grafindo Persada.

Kasmir. (2014). D asar-dasar Perbankan-E disi R evisi . Jakarta: Rajawali Pers.

Kotler, P. (2017). M anaj emen P emasaran. Jakarta: PT Macanan Jaya Cemerlang.

Muhammad. (2016). Sistem Bagi H asil dan Pricing Bank Syariah. Yogyakarta: UII Pers. 
Muhammad. (2002). M anajemen Bank Syariah. Yogyakarta: UPP AMP YKPN.

Mursid. (2010). M anajemen Pemasaran. Jakarta: Bumi Aksara.

Nurkhotimah, D. R. (2017). Pengaruh Indikator Keuangan Perbankan Terhadap Pangsa Pasar Perbankan Syariah Periode 2011-2015.

Otoritas Jasa Keuangan. (2017). Laporan Publikasi Perbankan Syariah.

Otoritas Jasa Keuangan. (2017). Statistik Perbankan Syariah.

Purboastuti, N., Anwar, N., \& Suryahani, I. (2015). Pengaruh Indikator Utama Perbankan terhadap Pangsa Pasar perbankan Syariah. JEJA K : Jurnal Ekonomi dan Kebijakan, 8(1).

Rahman, A. (2016). Analisis Faktor-Faktor Yang M empengaruhi Market Share Bank Syariah (Doctoral dissertation, Pascasarjana UIN Sumatera Utara).

Rivai, V. (2007). Bank dan Financial Institution M anagemen Conventional \& Syaria System. Jakarta: PT. Raja Grefindo Persada.

Santoso, M. R., \& Sholahuddin, M. (2018). Pengaruh Pembiayaan Terhadap O mset Penjualan, Laba U saha, M odal U saha Dan Total A set UMKM (Studi Kasus PT. BPRS Dana Mulia Surakarta) (Doctoral dissertation, Universitas Muhammadiyah Surakarta).

Siregar, E. S. (2019). Analisis Pengaruh Faktor Internal dan Eksternal Perbankan Syariah terhadap Market Share Aset Perbankan Syariah di Indonesia. Z hafir| Journal of Islamic E conomics, Finance, and Banking, 1(1), 39-50.

Syariah, B. N. I., \& Tahun, T. (2005). Prospek Bank Syariah Pasca Fatwa MUI. Y ogyakarta, Suara.

Syariah, B. N. I., \& Tahun, T. (2005). Prospek Bank Syariah Pasca Fatwa MUI. Y ogyakarta, Suara.

Syukron, A. (2013). Dinamika perkembangan perbankan syariah di Indonesia. Economic: Journal of Economic and Islamic Law, 3(2), 28-53.

Tjiptono, F. (2016). Pemasaran Esensi dan A plikasi. Yogyakarta: Andi Offset. 